\title{
Development and in vitro evaluation of an acid buffering bioadhesive vaginal gel for mixed vaginal infections
}

\author{
FARHAN JALEES AHMAD \\ MOHD AFTAB ALAM* \\ ZEENAT IQBAL KHAN \\ ROOP KRISHEN KHAR \\ MUSHIR ALI \\ Department of Pharmaceutics \\ Faculty of Pharmacy \\ Hamdard University \\ New Delhi-110062, India
}

Accepted September 16, 2008

\begin{abstract}
An acid buffering bioadhesive vaginal (ABBV) gel was developed for the treatment of mixed vaginal infections. Different bioadhesive polymers were evaluated on the basis of their bioadhesive strength, stability and drug release properties. Bioadhesion and release studies showed that guar gum, xanthan gum and hydroxypropyl methylcelullose K4M formed a good combination of bioadhesive polymers to develop the ABBV gel. Monosodium citrate was used as an acid buffering agent to provide acidic $\mathrm{pH}$ (4.4). The drugs clotrimazole (antifungal) and metronidazole (antiprotozoal as well as antibacterial) were used in the formulation along with Lactobacillus spores to treat mixed vaginal infections. The ex vivo retention study showed that the bioadhesive polymers hold the gel for 12-13 hours inside the vaginal tube. Results of the in vitro antimicrobial study indicated that the ABBV gel had better antimicrobial action than the commercial intravaginal drug delivery systems and retention was prolonged in an ex vivo retention experiment.
\end{abstract}

Keywords: acid buffering gel, vaginal bioadhesion, bioadhesive polymers, mixed vaginal infections

Vaginitis is a very common gynecological problem in women of all age groups. There are three types of infectious vaginitis: candidiasis, trichomoniasis, and bacterial vaginosis $(1,2)$. Vaginitis can be caused by single or mixed vaginal infections $(2-4)$. Approximately $30 \%$ of all cases of vaginitis are caused by simultaneous infections with at least two or more pathogens (e.g. bacterial vaginosis in patients of vulvovaginal candidiasis) (5). Vaginal infections can be diagnosed by clinical examinations, $\mathrm{pH}$ measurement and microscopic examination of vaginal discharge $(1,6)$. The $\mathrm{pH}$ of vaginal secretion is elevated (> 4.5) in case of bacterial vaginosis and trichomoniasis (1). Combination therapy may provide immediate and effective treatment for vaginal infections, irrespective of single or multiple types or even when the diagnosis is not precisely accurate (5).

* Correspondence, e-mail: afealam@rediffmail.com 
The conventional formulations of vaginal drug delivery systems (VDDS) are associated with poor retention due to the self-cleansing action of vaginal tract, leading to poor compliance (7). To overcome this problem, bioadhesive polymers are added to VDDS. Bioadhesive polymers can hold the drug delivery systems in the vaginal tube by interacting with vaginal mucosa and thereby increase patient compliance as well of delivery system efficiency $(8,9)$.

Bioadhesive polymers like hydroxypropyl methylcellulose (HPMC), sodium carboxymethyl cellulose (Na-CMC), xanthan gum, guar gum, sodium alginate show good stability in the wide range of $\mathrm{pH} 3-10$ and are hence good candidates for vaginal drug delivery systems at $\mathrm{pH} 3.8-4.5$. The drugs clotrimazole and metronidazole were selected because they are broad-spectrum antimicrobial agents $(10,11)$ and spores of Lactobacilli were added in the formulation to restore healthy microbial flora and acidic $\mathrm{pH}$ of the vagina $(3,12)$.

\section{EXPERIMENTAL}

\section{Materials}

Metronidazole, clotrimazole and Lactobacillus acidophilus spores were obtained as gift samples from Lark laboratories (India). Commercially available intravaginal formulations (Candid V - 2\% gel of clotrimazole in inactive gel base produced by Glenmark Pharmaceutical Ltd. India and Canesten $1-10 \%$ cream of clotrimazole in inactive cream base produced by Bayer, Germany) were purchased from the market. Bioadhesive polymers and monosodium citrate were obtained as gift samples from Ranbaxy (India) and Oscar Laboratories (India), respectively. Other chemicals used were of LR grade and immediately used after procurement. TAXT2i/Texture analyzer of Stable Microsystems was used to measure in vitro bioadhesion. The gel $\mathrm{pH}$ was measured using a surface $\mathrm{pH}$ electrode Orion 9135AP model, Aqua Pro flat surface $\mathrm{pH}$ (Thermo Electron Corporation, UK).

\section{Preparation of simulated vaginal fluid}

Simulated vaginal fluid (SVF) was prepared by dissolving sodium chloride, potassium hydroxide, calcium hydroxide, bovine serum albumin, lactic acid, acetic acid, glycerol, urea and glucose in water; $\mathrm{pH}$ was adjusted to 4.2 by using $1 \mathrm{~mol} \mathrm{~L}^{-1} \mathrm{HCl}$ (13).

\section{Gels}

Metronidazole was dissolved in water followed by dispersing the polymers. Carbopol and polycarbophil gel was prepared by neutralization with sodium hydroxide. Gels of cellulose derivatives and natural polymers (gums, alginate) were prepared by overnight soaking of the polymers for complete hydration. Clotrimazole and methylparaben were dispersed in the swelled gel under stirring. These gel formulations were developed to study the effect of individual gelling polymers on the drug release behavior. Gels of individual polymers were named GA, GB, GC, GD, GE, GF, GG, and GH and their compositions are given in Table I. 
F. Jalees Ahmad et al.: Development and in vitro evaluation of an acid buffering bioadhesive vaginal gel for mixed vaginal infections, Acta Pharm. 58 (2008) 407-419.

Table I. Composition of gels

\begin{tabular}{lcccccccc}
\hline \multirow{2}{*}{ Ingredient } & \multicolumn{8}{c}{ Gel formulation $(\%, m / m)$} \\
\cline { 2 - 9 } & GA & GB & GC & GD & GE & GF & GG & GH \\
\hline Metronidazole & 0.75 & 0.75 & 0.75 & 0.75 & 0.75 & 0.75 & 0.75 & 0.75 \\
Clotrimazole & 1.0 & 1.0 & 1.0 & 1.0 & 1.0 & 1.0 & 1.0 & 1.0 \\
Na-CMC & 4.0 & - & - & - & - & - & - & - \\
HPMC-K15M & - & 4.0 & - & - & - & - & - & - \\
HPMC-K100M & - & - & 4.0 & - & - & - & - & - \\
Na-alginate & - & - & - & 4.0 & - & - & - & - \\
Guar gum & - & - & - & - & 4.0 & - & - & - \\
Xanthan gum & - & - & - & - & - & 5.0 & - & - \\
Carbopol-971 & - & - & - & - & - & - & 1.0 & - \\
Polycarbophil & - & - & - & - & - & - & - & 1.0 \\
NaOH & - & - & - & - & - & - & 0.4 & 0.4 \\
Methylparaben & 0.2 & 0.2 & 0.2 & 0.2 & 0.2 & 0.2 & 0.2 & 0.2 \\
Water & q.s. & q.s. & q.s. & q.s. & q.s. & q.s. & q.s. & q.s. \\
\hline
\end{tabular}

q.s. - quantum satis

\section{Combination gels}

In combination gels, prolonged release polymers as well as fast eroding/swelling polymers were used and their effects on drug release and gel properties were optimized. Compositions of combination gels are given in Table II.

\section{Modified dissolution apparatus}

The USP dissolution apparatus II (14) was modified for release studies of gels. A circular, 2.38-mm mesh stainless steel net of $8.0 \mathrm{~cm}$ diameter was placed at the bottom of the dissolution vessel. A stainless steel plate of $5.5 \mathrm{~cm}$ internal diameter and $5 \mathrm{~mm}$ height, with $5 \mathrm{~g}$ gel, was placed on the wire net (15). The paddle was set at the height of $2.5 \mathrm{~cm}$ from the gel surface. The dissolution medium $(900 \mathrm{~mL})$ for gels and combination gels was $0.5 \%(m / V)$ solution of sodium lauryl sulphate in water. For acid buffering gel, the dissolution medium was $900 \mathrm{~mL}$ of simulated vaginal fluid with $0.5 \%(\mathrm{~m} / \mathrm{V})$ sodium lauryl sulphate. Paddle speed was set to $50 \mathrm{rpm}$ and the temperature was maintained at $37 \pm 0.5^{\circ} \mathrm{C}$. The sampling volume was replaced by fresh dissolution medium.

\section{In vitro adhesion tests}

The in vitro mucoadhesive properties of combination gels were assessed on bovine vaginal mucosa, using a TAXT2i Texture Analyzer. The test parameters were: pretest speed $0.5 \mathrm{~mm} \mathrm{~s}^{-1}$, test speed $0.1 \mathrm{~mm} \mathrm{~s}^{-1}$, contact time $3.0 \mathrm{~min}$, preload $1 \mathrm{~N}$, load cell 500 $\mathrm{N}$, diameter of upper probe $36 \mathrm{~mm}$. The experiment was carried out at room temperature. 
F. Jalees Ahmad et al.: Development and in vitro evaluation of an acid buffering bioadhesive vaginal gel for mixed vaginal infections, Acta Pharm. 58 (2008) 407-419.

Table II. Composition of combination gels

\begin{tabular}{|c|c|c|c|c|c|c|c|c|c|c|c|c|c|c|}
\hline \multirow{2}{*}{ Ingredient } & \multicolumn{14}{|c|}{ Gel formulations $(\%, m / m)$} \\
\hline & G1 & G2 & G3 & G4 & G5 & G6 & G7 & G8 & G9 & G10 & G11 & G12 & G13 & G14 \\
\hline Metronidazole & 0.75 & 0.75 & 0.75 & 0.75 & 0.75 & 0.75 & 0.75 & 0.75 & 0.75 & 0.75 & 0.75 & 0.75 & 0.75 & 0.75 \\
\hline Clotrimazole & 1.0 & 1.0 & 1.0 & 1.0 & 1.0 & 1.0 & 1.0 & 1.0 & 1.0 & 1.0 & 1.0 & 1.0 & 1.0 & 1.0 \\
\hline Guar gum & 2 & 2 & 2 & - & - & - & 2 & - & 2 & - & 1.5 & 1.5 & - & - \\
\hline $\mathrm{Na}-\mathrm{CMC}$ & 2 & - & - & - & 1.5 & - & - & - & - & - & - & - & - & - \\
\hline HPMC-K15M & - & 2 & - & 2 & - & - & - & - & - & - & - & - & - & - \\
\hline HPMC-K4M & - & - & 2 & - & - & 2 & - & - & 1 & 1 & 0.5 & 0.5 & 0.5 & 0.5 \\
\hline Na-alginate & - & - & - & 2 & 2 & 2 & - & 2 & - & 2 & - & - & 1.5 & 1.5 \\
\hline Xanthan gum & - & - & - & - & - & - & 2 & 2 & 1 & 1 & - & - & - & - \\
\hline Carbopol & - & - & - & - & - & - & - & - & - & - & 0.5 & - & 0.5 & - \\
\hline Polycarbophil & - & - & - & - & - & - & - & - & - & - & - & 0.5 & - & 0.5 \\
\hline $\mathrm{NaOH}$ & - & - & - & - & - & - & - & - & - & - & 0.2 & 0.2 & 0.2 & 0.2 \\
\hline Glycerin & 30 & 30 & 30 & 30 & 30 & 30 & 30 & 30 & 30 & 30 & 30 & 30 & 30 & 30 \\
\hline Methylparaben & 0.2 & 0.2 & 0.2 & 0.2 & 0.2 & 0.2 & 0.2 & 0.2 & 0.2 & 0.2 & 0.2 & 0.2 & 0.2 & 0.2 \\
\hline Water & q.s. & q.s. & q.s. & q.s. & q.s. & q.s. & q.s. & q.s. & q.s. & q.s. & q.s. & q.s. & q.s. & q.s. \\
\hline
\end{tabular}

q.s. - quantum satis

The vaginal mucosal tissue was cleaned, washed and stored at $-20{ }^{\circ} \mathrm{C}$. The stored vaginal tissue was treated with $0.1 \%(\mathrm{~m} / \mathrm{V})$ sodium azide and allowed to reach normal temperature before commencement of the experiment. Preserved, cleaned and thawed vaginal mucosa was incised longitudinally just before the experiment. Vaginal tissue was mounted on the platform below the texture analyzer probe. A cellophane membrane, equilibrated with SVF at room temperature for 24 hours was tied to the upper probe. Surface of vaginal mucosa was moisturized with simulated vaginal fluid and gel was applied. The test was run after completing the pre-test requirements.

\section{Development of an acid buffering prolonged release bioadhesive gel}

Composition of ABBV gel is given in Table III. The ingredients metronidazole, monosodium citrate, Lactobacilli, methylparaben and glycerin were dispersed in water. The polymers were dispersed in this solution under stirring and the composition was allowed to swell for $24 \mathrm{~h}$. Finally, clotrimazole was mixed under stirring into the swollen gel.

\section{Apparatus for ex vivo retention studies}

The apparatus for ex vivo retention studies consisted of a glass cell, peristaltic pump, beaker, thermometer, magnetic stirrer and vaginal mucosa. The cell was a glass tube (length $11.0 \mathrm{~cm}$, external diameter $5.0 \mathrm{~cm}$ ) with openings at both ends; the diameter of 
F. Jalees Ahmad et al.: Development and in vitro evaluation of an acid buffering bioadhesive vaginal gel for mixed vaginal infections, Acta Pharm. 58 (2008) 407-419.

Table III. Composition of the acid buffering bioadhesive gel ( $p H$ 4.4)

\begin{tabular}{lc}
\hline Ingredient & Quantity \\
\hline Metronidazole & $0.75 \mathrm{~g}$ \\
Clotrimazole & $1.0 \mathrm{~g}$ \\
HPMC-K4M & $1.5 \mathrm{~g}$ \\
Guar gum & $1.5 \mathrm{~g}$ \\
Xanthan gum & $1.0 \mathrm{~g}$ \\
Glycerin & $30 \mathrm{~mL}$ \\
Na-monocitrate & $200 \mathrm{mg}$ \\
Lactobacillus & $500 \mathrm{mg}$ \\
Methylparaben & $200 \mathrm{mg}$ \\
Water & q.s. $100 \mathrm{~g}$ \\
\hline
\end{tabular}

q.s. - quantum satis

the upper opening was $2.4 \mathrm{~cm}$ and $1.0 \mathrm{~cm}$ of the lower opening. The edges of upper and lower openings were molded to aid in tying the tissue properly. Two small side arms were present at both ends of the glass cell, placed $4.5 \mathrm{~cm}$ apart from each other; the lower side arm was used as inlet and the upper as outlet. Distilled water was circulated through these side arms into the glass cell by a pump. A peristaltic pump was used to circulate the SVF through the vaginal tract. Temperature of SVF and the circulating liquid was maintained at $37^{\circ} \mathrm{C}$. Apparatus for ex vivo studies was a modified version of the Setnikar and Fantelli apparatus (16).

\section{Ex vivo retention measurement}

An intact tubular piece of processed and preserved bovine vaginal mucosa was cut to proper size and vertically mounted in a glass cell. The ends of the vaginal mucosal tube were averted on the tapering of the upper and lower ends of the glass cell and crimped using rubber bands so that both ends of the vaginal tube remained open. Distilled water $\left(37^{\circ} \mathrm{C}\right)$ was circulated through the cell using a pump. This circulating water maintained the temperature, equivalent to body temperature, and kept the tissue moist from the outside. The $5 \mathrm{~g}$ acid buffering bioadhesive gel/Canesten- 1 cream was inserted into the vaginal tube using an applicator. After putting the formulation inside the vaginal tube, a preload time of five minutes was allowed so that the formulation got adhered to the vaginal walls. Simulated vaginal fluid was allowed to fall dropwise into the vertically suspended vaginal tube holding the formulation, using a peristaltic pump. The rate of simulated vaginal fluid was maintained at $3 \mathrm{~mL} \mathrm{~h}^{-1}$ and expulsion of the formulation was recorded from the lower end of the cell.

\section{pH determination}

The $\mathrm{pH}$ of the acid buffering bioadhesive gel was measured by putting the tip of surface electrode to the gel surface and the results were taken as a mean of three determinations. 


\section{Measurement of gel spreadability}

Concentric circles of different radii were drawn on graph paper and a glass plate was fixed onto it. Gel $(5.0 \mathrm{~g})$ was transferred to the centre of the lower plate and spread over an area of $2 \mathrm{~cm}$ diameter. The glass plate of $100 \pm 5 \mathrm{~g}$ was placed gently on the gel and the spread diameter was recorded after 1 minute; subsequent glass plates were added and the spread diameter was recorded after 1 minute of each addition. Results were presented as the spreading area being a function of the applied mass (17). Spreadability of the developed formulation was compared with the commercial formulation Candid-V gel.

\section{Antifungal and antimicrobial studies}

The in vitro antimicrobial studies were carried out by the cup plate method using Candida albicans and Escherichia coli microorganisms.

Sterilized Sabouraud's agar/nutrient agar medium $(25 \mathrm{~mL})$ was poured into sterilized Petri plates (diameter $15 \mathrm{~cm}$ ) under laminar air flow and allowed to solidify. The 0.4 $\mathrm{mL}$ aqueous suspension of Candida albicans/Escherichia coli was spread uniformly on solidified Sabouraud's agar/nutrient agar medium. The cups were cut and formulations were filled into different cups using sterilized syringes, under laminar air flow. Plates were covered with lids and incubated in BOD at $32{ }^{\circ} \mathrm{C}$ for 40 hours. The zones of inhibition were measured after 40 hours.

\section{RESULTS AND DISCUSSION}

\section{Gels and combination gels}

Gels with particular polymers were prepared to study the effect of each polymer on the release profile (Table IV). The gels GA (Na-CMC, 4\%), GB (HPMC-K15M, 4\%), GC (HPMC-K100M, 4\%), GF (xanthan gum, 5\%), GG (Carbopol-971, 1\%), and GH (polycarbophil, 1\%) released more than $95 \%$ of metronidazole within $3 \mathrm{~h}$. All these gels except GA released $100 \%$ of clotrimazole within $4 \mathrm{~h}$. In gels GA, GB, GC, GF, GG and GH, the dissolution or erosion of the gelling polymer was rapid and most of the gel got dissolved within $4 \mathrm{~h}$. Sodium alginate (GD) and guar gum (GE) gels showed integrity beyond $7 \mathrm{~h}$ and did not dissolve completely even after $7 \mathrm{~h}$. In gels with particular polymers, the release of metronidazole was faster compared to clotrimazole since metronidazole was in solution form in the gel matrix whereas clotrimazole was suspended in the hydrophilic gel matrix. Guar gum and sodium alginate were selected as a stable base forming material in combination with other fast dissolving polymers so that the integrity of the gel could be maintained up to $5 \mathrm{~h}$.

Combination gels, namely gels with a combination of polymers showed prolonged release dissolution profiles (Table V). The prolonged integrity and release from these gels (gel-G1 to gel-G14, gels with different polymer ratios) were achieved by using guar gum or sodium alginate as rigid gel structure forming agents. As the erosion/dissolution of guar gum and sodium alginate gels is very slow, fast dissolving/eroding polymers were used in combination with these slow eroding polymers in different composi- 
F. Jalees Ahmad et al.: Development and in vitro evaluation of an acid buffering bioadhesive vaginal gel for mixed vaginal infections, Acta Pharm. 58 (2008) 407-419.

Table IV. Cumulative percent release profiles of gels

\begin{tabular}{|c|c|c|c|c|c|c|c|}
\hline \multirow{2}{*}{$\begin{array}{l}\text { Formu- } \\
\text { lation }\end{array}$} & \multirow{2}{*}{$\begin{array}{l}\text { Time } \\
(\min )\end{array}$} & \multicolumn{2}{|c|}{ Release (\%) } & \multirow{2}{*}{$\begin{array}{l}\text { Formu- } \\
\text { lation }\end{array}$} & \multicolumn{3}{|c|}{ Release (\%) } \\
\hline & & Metronidazole & Clotrimazole & & $\begin{array}{l}\text { Time } \\
(\mathrm{min})\end{array}$ & Metronidazole & Clotrimazole \\
\hline \multirow[t]{6}{*}{ GA } & 0 & 0 & 0 & GE & 0 & - & 0 \\
\hline & 30 & 78.0 & 24.4 & & 60 & - & 19.5 \\
\hline & 60 & 90.0 & 36.6 & & 120 & - & 28.6 \\
\hline & 120 & 95.3 & 73.9 & & 180 & - & 34.5 \\
\hline & 240 & 99.0 & 83.5 & & 240 & - & 43.0 \\
\hline & 420 & 99.0 & 94.3 & & 300 & - & 53.3 \\
\hline \multirow[t]{6}{*}{ GB } & 0 & 0 & 0 & GF & 0 & 0 & 0 \\
\hline & 30 & 72.0 & 46.0 & & 10 & 55.6 & 20.0 \\
\hline & 60 & 96.0 & 94.0 & & 30 & 63.9 & 25.6 \\
\hline & 120 & 99.0 & 95.2 & & 90 & 76.0 & 31.9 \\
\hline & 240 & 99.0 & 104.2 & & 210 & 88.2 & 70.4 \\
\hline & 420 & 99.0 & 104.0 & & 330 & 92.4 & 108.1 \\
\hline \multirow[t]{5}{*}{ GC } & 0 & 0 & 0 & GG & 0 & 0 & 0 \\
\hline & 30 & 67.2 & 34.1 & & 30 & 86.4 & 80.7 \\
\hline & 60 & 81.6 & 57.0 & & 60 & 96.0 & 101.8 \\
\hline & 120 & 98.7 & 82.4 & & 120 & 98.7 & 105.4 \\
\hline & 240 & 98.7 & 100 & & 240 & 100.1 & 105.4 \\
\hline \multirow[t]{6}{*}{ GD } & 0 & 0 & 0 & GH & 0 & 0 & 0 \\
\hline & 60 & 31.2 & 25.9 & & 30 & 76.8 & 53.2 \\
\hline & 120 & 41.1 & 38.6 & & 60 & 96.0 & 83.9 \\
\hline & 180 & 46.6 & 45.9 & & 120 & 96.0 & 106.4 \\
\hline & 240 & 53.8 & 54.6 & & 240 & 100.8 & 106.4 \\
\hline & 300 & 62.6 & 65.8 & & & & \\
\hline
\end{tabular}

Table V. Cumulative percent release profiles of combination gels

\begin{tabular}{cccccccc}
\hline \multirow{2}{*}{$\begin{array}{c}\text { Formu- } \\
\text { lation }\end{array}$} & \multirow{2}{*}{$\begin{array}{c}\text { Time } \\
(\mathrm{min})\end{array}$} & \multicolumn{2}{c}{ Release $(\%)$} & Formu- & Time & \multicolumn{2}{c}{ Release $(\%)$} \\
\cline { 3 - 4 } & & Metronidazole & Clotrimazole & lation & (min) & Metronidazole Clotrimazole \\
\hline G1 & 0 & 0 & 0 & G8 & 0 & 0 & 0 \\
& 30 & 52.8 & 22.6 & & 10 & 6.2 & 15.5 \\
& 60 & 67.2 & 32.4 & & 30 & 6.2 & 19.7 \\
& 120 & 91.2 & 54.9 & & 90 & 7.9 & 21.1 \\
& 240 & 98.7 & 89.1 & & 210 & 21.1 & 42.4 \\
& 360 & 100.0 & 100.9 & & 330 & 32.7 & 51.8
\end{tabular}


F. Jalees Ahmad et al.: Development and in vitro evaluation of an acid buffering bioadhesive vaginal gel for mixed vaginal infections, Acta Pharm. 58 (2008) 407-419.

\begin{tabular}{|c|c|c|c|c|c|c|c|}
\hline \multirow[t]{6}{*}{ G2 } & 0 & 0 & 0 & G9 & 0 & 0 & 0 \\
\hline & 10 & 32.2 & 27.7 & & 10 & 32.1 & 31.9 \\
\hline & 30 & 37.9 & 37.8 & & 30 & 36.8 & 35.7 \\
\hline & 90 & 59.9 & 70.0 & & 90 & 51.8 & 53.1 \\
\hline & 210 & 76.1 & 86.8 & & 210 & 79.6 & 77.2 \\
\hline & 330 & 95.8 & 100.4 & & 330 & 99.2 & 100.9 \\
\hline \multirow[t]{6}{*}{ G3 } & 0 & 0 & 0 & G10 & 0 & 0 & 0 \\
\hline & 10 & 28.7 & 21.1 & & 10 & 10.3 & 14.8 \\
\hline & 30 & 36.8 & 23.5 & & 30 & 21.1 & 15.4 \\
\hline & 90 & 55.3 & 53.9 & & 90 & 35.2 & 38.2 \\
\hline & 210 & 63.4 & 75.9 & & 210 & 65.8 & 73.8 \\
\hline & 330 & 77.3 & 103.9 & & 330 & 84.0 & 107.4 \\
\hline \multirow[t]{6}{*}{ G4 } & 0 & 0 & 0 & G11 & 0 & 0 & 0 \\
\hline & 10 & 33.3 & 34.7 & & 10 & 25.2 & 23.5 \\
\hline & 30 & 50.7 & 39.2 & & 30 & 24.4 & 25.3 \\
\hline & 90 & 61.1 & 71.7 & & 90 & 41.8 & 28.8 \\
\hline & 210 & 73.8 & 88.2 & & 210 & 57.5 & 36.8 \\
\hline & 330 & 85.3 & 96.6 & & 330 & 65.8 & 37.5 \\
\hline \multirow[t]{6}{*}{ G5 } & 0 & 0 & 0 & G12 & 0 & 0 & 0 \\
\hline & 10 & 33.3 & 31.6 & & 10 & 18.6 & 29.1 \\
\hline & 30 & 36.8 & 39.9 & & 30 & 30.2 & 30.9 \\
\hline & 90 & 52.8 & 67.9 & & 90 & 46.7 & 35.7 \\
\hline & 210 & 66.8 & 87.5 & & 210 & 67.4 & 43.1 \\
\hline & 330 & 70.3 & 90.6 & & 330 & 71.6 & 44.8 \\
\hline \multirow[t]{6}{*}{ G6 } & 0 & 0 & 0 & G13 & 0 & 0 & 0 \\
\hline & 10 & 33.3 & 33.6 & & 10 & 21.9 & 22.5 \\
\hline & 30 & 39.1 & 40.3 & & 30 & 28.5 & 26.0 \\
\hline & 90 & 61.1 & 69.3 & & 90 & 42.6 & 27.7 \\
\hline & 210 & 80.7 & 101.8 & & 210 & 58.3 & 32.6 \\
\hline & 330 & 93.4 & 106.0 & & 330 & 67.7 & 41.1 \\
\hline \multirow[t]{6}{*}{ G7 } & 0 & 0 & 0 & G14 & 0 & 0 & 0 \\
\hline & 10 & 3.7 & 16.2 & & 10 & 25.2 & 23.2 \\
\hline & 30 & 4.5 & 28.1 & & 30 & 29.4 & 30.2 \\
\hline & 90 & 7.9 & 29.5 & & 90 & 60.0 & 49.7 \\
\hline & 210 & 17.8 & 33.3 & & 210 & 69.1 & 58.1 \\
\hline & 330 & 24.4 & 42.9 & & 330 & 80.7 & 64.8 \\
\hline
\end{tabular}


tions to improve the release pattern of the drugs. To further retard the release of the water-soluble drug metronidazole, the drug was mixed with ethyl cellulose (3\%) using isopropyl alcohol as granulating agent. The release profile of gels G1 to G6 was prolonged and almost similar, because the polymers used in these gels had almost identical dissolution behavior (HPMC and Na-CMC) and a strong structure forming property (guar gum and sodium alginate) (G1 guar gum 2\% + Na-CMC 2\%, G2 guar gum 2\% + HPMC-K15M $2 \%$, G3 guar gum 2\% + HPMC-K4M 2\%, G4 Na-alginate 2\% + HPMC-K15M 2\%, G5 Na-alginate $2 \%+$ Na-CMC $1.5 \%$ and G6 Na-alginate $\%$ + HPMC-K4M 2\%). The release of the drug from gels G7 and G8 containing xanthan gum was more prolonged compared to gels G1 to G6 (G7 xanthan gum 2\% + guar gum 2\% and G8 xanthan gum 2\% + Na-alginate $2 \%$ ). As the erodability and swelling nature of xanthan gum are lower than those of Na-CMC and HPMC, the release through gels containing xanthan gum was prolonged. In gels G9 and G10, the amount of structure forming agents (guar gum or Na-alginate) was kept constant $(2 \%)$ but the fast dissolving polymer (HPMC-K4M) was used in combination, so that an aesthetic and desirable gel with good bioadhesive strength could be achieved (G9 xanthan gum 1\%, HPMC-K4M 1\% + guar gum 2\% and G10 xanthan gum 1\%, HPMC-K4M 1\% + Na-alginate 2\%). The release profile of gels G9 and G10 was more or less similar to gels G1 to G6. Physical incompatibility was observed in G11 to G14 (G7 xanthan gum 2\% + guar gum 2\% and G8 xanthan gum 2\% + Na-alginate $2 \%$; the gels turned yellow when carbopol and polycarbophil were neutralized by sodium hydroxide in the presence of guar gum or sodium alginate. The release profiles of these gels were much prolonged.

\section{In vitro bioadhesion}

The force required to detach the formulation from the surface of tissue was determined as the "peak value" in the resultant force-time plot (Fig. 1). The bioadhesive strength of combination gel formulations is given in Fig. 2. The bioadhesive strength of G9 formulation was found to be $0.524 \mathrm{~N}$, pointing to good bioadhesion. Release profile of G9 gel was prolonged and uniform for both drugs. The G9 formulation was selected for the development of an acid buffering bioadhesive vaginal gel formulation.

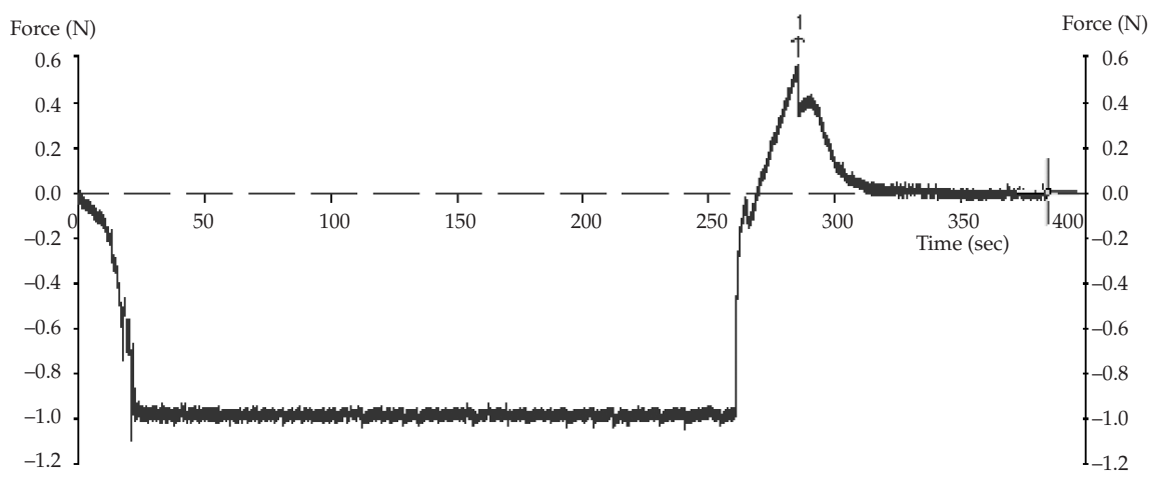

Fig. 1. Representative graph of the in vitro bioadhesion test. 


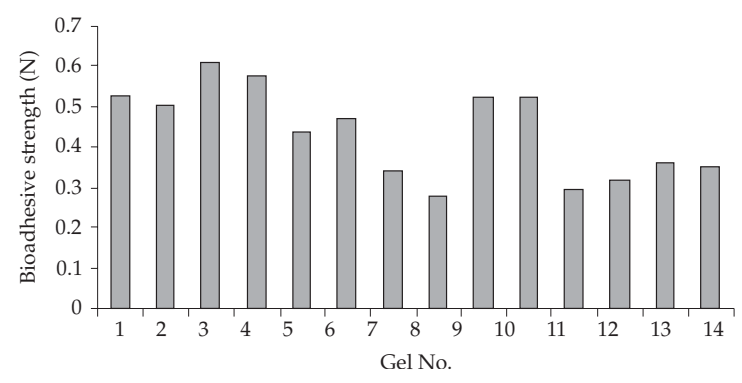

Fig. 2. Bioadhesive strength of combination gels.

\section{Acid buffering bioadhesive vaginal gel}

On the basis of its drug release profile and bioadhesive strength, the gel formulation G9 was selected for the development of an acid buffering prolonged release bioadhesive gel. Metronidazole, clotrimazole and Lactobacilli were used as a broad-spectrum combination. Monosodium citrate was used to maintain $\mathrm{pH} 4.4$ of the acid buffering prolonged release bioadhesive gel (18). Guar gum was used in the formulation to provide a rigid gel and a prolonged releasing component. Xanthan gum and HPMC-K4M were used to provide smoothness and better spreadability along with improved release properties. All of these bioadhesive polymers are stable over a wide range of $\mathrm{pH}(3-10)$. In the ex vivo experiment, the ABBV gel retention time was up to 12-13 $\mathrm{h}$. The developed ABBV gel showed more resistance to viscosity changes due to SVF absorption and thus showed better retention than the commercial vaginal gel/cream which started to leak within 5-6 h. Besides, creams do not have the capacity to absorb and hold fluid since bioadhesive gels do and leak out when the surface of the vaginal wall gets lubricated by simulated vaginal fluid. Good spreadability of the semisolid formulation is required for better action. Spreadability of the developed gel was found to be poor compared to commercial gel (Candid-V gel) (Fig. 3). The reason for poor spreadability of acid buffering gel was its high viscosity and the presence of the rigid gel forming agent, guar gum. These parameters speak in favor of better bioadhesion and prolonged retention of the gel. Almost $100 \%$ drug released from the ABBV gel, within $6 \mathrm{~h}$ while only $84 \%$ drug released from Candid-V gel in $6 \mathrm{~h}$ (Fig. 4). Physical appearance of the gel was evaluated with naked eye. The gel was smooth, without any lumps and of uniform white color. No color change/liquefication/separation were observed after six-month storage at $40{ }^{\circ} \mathrm{C}$, $75 \% \mathrm{RH}$.

Fig. 3. Spreadability study of the acid buffering bioadhesive gel and Candid-V gel.

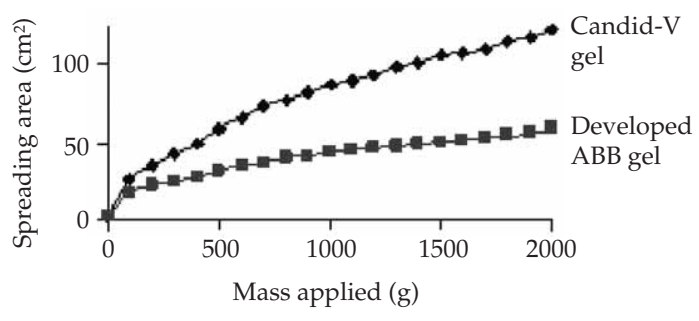


Fig. 4. Cumulative percent release profiles from combined acid buffering bioadhesive gels and Candid$-\mathrm{V}$ gel ( $\bar{X} \pm \mathrm{SD}, n=3)$.

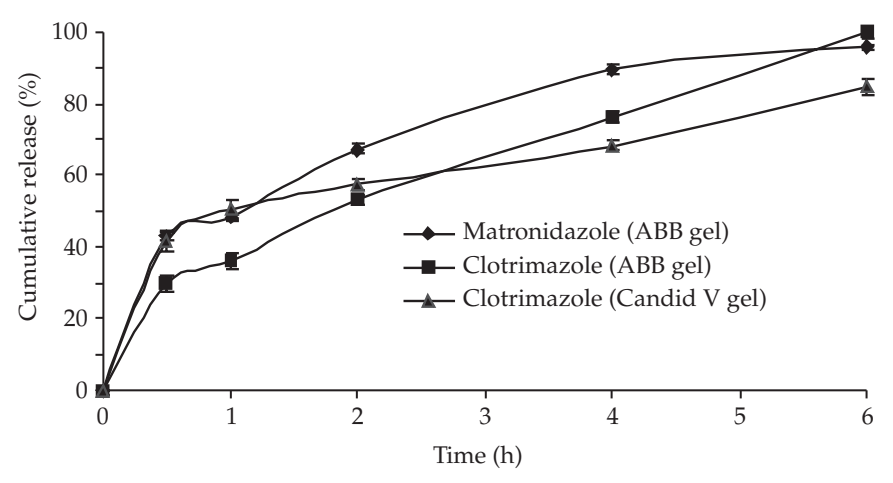

\section{Antimicrobial studies}

The in vitro efficacy of the developed ABBV gel was compared with commercial gel/cream formulations. Developed gel was found to be more effective in in vitro conditions. The average zone of inhibition of the developed ABBV gel against Candida albicans was $32.3 \pm 0.6 \mathrm{~mm}$ compared to $25.3 \pm 0.6 \mathrm{~mm}$ and $25.3 \pm 0.6 \mathrm{~mm}$ of commercial formulations Canesten- 1 and Candid- $\mathrm{V}$ gel, respectively, indicating significantly higher efficacy of ABBV gel $(p>0.001)$. Average zone of inhibition of the developed ABBV gel against E. coli was $23.0 \pm 0.0 \mathrm{~mm}$ compared to $21.0 \pm 0.0 \mathrm{~mm}$ of Candid-V gel. From the results of in vitro antimicrobial activity it is clear that the developed ABBV gel was more effective than the tested commercial formulations.

\section{CONCLUSIONS}

An acid buffering bioadhesive vaginal gel was developed for the treatment of single as well as mixed vaginal infections. The developed bioadhesive gel was found to have prolonged ex vivo retention. The in vitro results of antimicrobial activity suggest that the acid buffering bioadhesive gel was more efficacious than the commercial formulations tested.

Acknowledgements. - The authors are thankful to U. G. C. New Delhi (India), for providing financial assistance. The authors are also thankful to Mr. Praveen Sharma (Manager, Scientific and Digital Systems) and Mr. Anuranjan Pandaya (Application Engineer) for providing the TAXT2i Texture Analyzer of stable Microsystems for in vitro bioadhesion studies. We also thank Mr. Bibhu Prasad Panda (Lecturer) and Mr. Sadique (Scholar), Department of Biotechnology for their kind support during antimicrobial activity. 
F. Jalees Ahmad et al.: Development and in vitro evaluation of an acid buffering bioadhesive vaginal gel for mixed vaginal infections, Acta Pharm. 58 (2008) 407-419.

\section{REFERENCES}

1. J. Sherrard, European guidelines for the management of vaginal discharge, Int. J. STD AIDS 12 (2001) 73-77.

2. S. Kukner, T. Ergin, N. Cicek, M. Ugur, H. Yesilyurt and O. Gokmen, Treatment of vaginitis, Int. J. Gynecol. Obstet. 52 (1996) 43-47; DOI: 10.1016/0020-7292(95)02531-6.

3. Vaginitis ACOG Technical Bulletin, Int. J. Gynecol. Obstet. 53 (1996) 271-280; DOI: 10.1016/S0020-7292(96)90014-4.

4. P. A. Mardh, K. Tchoudomirova, S. Elshibly and D. Hellberg, Symptoms and signs in single and mixed genital infections, Int. J. Gynecol. Obstet. 63 (1998) 145-152; DOI: 10.1016/S0020-7292(98) 00140-4.

5. E. Ozyurt, M. B. Toykuliyeva, I. L. Danilyans, O. Morton and G. Baktir, Efficacy of 7-day treatment with metronidazole + miconazole (Neo-Penotran $\left.{ }^{\circledR}\right)$ - a triple-active pessary for the treatment of single and mixed vaginal infections, Int. J. Gynecol. Obstet. 74 (2001) 35-43; DOI: 10.1016/ S0020-7292(01)00388-5.

6. J. Thinkhamrop, P. Lumbiganon, P. Thongkrajai and C. Chongsomchai, Vaginal $\mathrm{pH}$ as a screening test for vaginitis, Int. J. Gynecol. Obstet. 66 (1999) 143-148; DOI: 10.1016/S0020-7292(99) 00057-0.

7. G. C. Ceschel, P. Maffei, S. L. Borgia, C. Ronchi and S. Rossi, Development of a mucoadhesive dosage form for vaginal administration, Drug Dev. Ind. Pharm. 27 (2001) 541-547; DOI: 10.1081/ DDC-100105179.

8. K. Vermani and S. Garg, The scope and potential of vaginal drug delivery, Pharm. Sci. Technol. Today 3 (2000) 359-364; DOI: 10.1016/S1461-5347(00)00296-0.

9. R. S. Levinson and D. J. Thompson, VagiSite bioadhesive technology, Drugs Pharm. Sci. 126 (2003) 801-806.

10. C. D. Freeman, N. E. Klutman and K. C. Lamp, Metronidazole, a therapeutic review and update, Drugs 54 (1997) 679-708.

11. P. H. Spiekermann and M. D. Young, Clinical evaluation of clotrimazole. A broad-spectrum antifungal agent, Arch. Dermatol. 112 (1976) 350-352.

12. L. Maggi, P. Mastromarino, S. Macchia, P. Brigidi, F. Pirovano, D. Matteuzzi and U. Conte, Technological and biological evaluation of tablets containing different strains of Lactobacilli for vaginal administration, Eur. J. Pharm. Biopharm. 50 (2000) 389-395; DOI: 10.1016/S0939-6411(00)00121-1.

13. D. H. Owen and D. F. Katz, A vaginal fluid stimulant, Contraception 59 (1999) 91-95; DOI: 10.1016/ S0010-7824(99)00010-4.

14. United States Pharmacopoeia 26 - National Formulary 21, Asian Edition, USP Convention, Rockville (MD) 2003, pp. 2155-2156.

15. H-L. Weng and E. L. Parrott, Dissolution apparatus for gels, J. Pharm. Sci. 72 (1983) 186-188; DOI: $10.1002 /$ jps.2600720223.

16. M. A. Alam, F. J. Ahmad, Z. I. Iqubal, R. K. Khar and M. Ali, Development and evaluation of acid-buffering bioadhesive vaginal tablet for mixed vaginal infections, AAPS PharmSciTech. 8 (2007) 229-236.

17. I. C. De Paula, G. G. Ortega, V. L. Bassani and P. R. Petrovick, Development of ointment formulations prepared with Achyrocline satureioides spray dried extracts, Drug Dev. Ind. Pharm. 24 (1998) 235-241.

18. L. Kaus, Buffers and Buffering Agents, in Encyclopedia of Pharmaceutical Technology (Eds. J. Swarbrick and J. C. Boylan), Vol. 2, Marcel Dekker, New York 1990, pp. 213-231. 
F. Jalees Ahmad et al.: Development and in vitro evaluation of an acid buffering bioadhesive vaginal gel for mixed vaginal infections, Acta Pharm. 58 (2008) 407-419.

$S A \check{Z} E T A K$

\section{Razvoj i in vitro vrednovanje puferiranog bioadhezivnog vaginalnog gela za miješane vaginalne infekcije}

FARHAN JALEES AHMAD, MOHD AFTAB ALAM, ZEENAT IQBAL KHAN, ROOP KRISHEN KHAR i MUSHIR ALI

$\mathrm{U}$ radu je opisan razvoj puferiranog biodhezivnog vaginalnog (acid buffering bioadhesive vaginal, $\mathrm{ABBV}$ ) gela za terapiju miješanih vaginalnih infekcija. Ispitani su različiti bioadhezivni polimeri - procijenjena su njihova bioadhezivna svojstva, stabilnost i sposobnost oslobađanja ljekovite tvari. Guar guma, ksantan guma i hidroksipropilmetilceluloza K4M tvore dobru kombinaciju za ABBV gel. Mononatrijev citrat upotrebljen je kao puferirajuća tvar koja omogućava blago kiseli $\mathrm{pH}(4,4)$, a kao ljekovite tvari upotrebljeni su klotrimazol (antimikotik) i metronidazol (antiprotozoik i antibakterijsko sredstvo), zajedno sa sporama Lactobacillus. Pripravci su upotrebljeni u terapiji miješanih vaginalnih infekcija. Pokusi ex vivo pokazali su da se bioadhezivni gel zadržava u vagini 12-13 sati. Rezultati in vitro ispitivanja ukazuju na to da ABBV gel ima bolje antibakterijsko djelovanje i dulje zadržavanje od intravaginalnog sustava koji je dostupan na tržištu.

Ključne riječi: puferirani gel, vaginalna bioadhezija, bioadhezivni polimeri, miješane vaginalne infekcije Department of Pharmaceutics, Faculty of Pharmacy, Hamdard University, New Delhi-110062, India 